\title{
The Structure and Mode of Life of a Form of Hormidium flaccidum, A. Braun. ${ }^{1}$
}

BV

\section{ALMA PIERCY, M.SC。 \\ With three Tables and six Figures in the Text.}

I. INTRODUCTORY。

T recent years a considerable amount of work has been published on the 1 development and reproduction of Green Algae, but little attention has been paid as a rule to the way in which they vary in response to changes in the external conditions. Fritsch and Rich, ${ }^{2}$ among others, refer to a special 'winter form' of Cladophora, produced by the cells of the ordinary filaments thickening their walls, darkening in colour, and accumulating abundant starch, besides often assuming an irregular, inflated shape. Few other data are to be found in the literature. It is to be supposed that terrestrial Algae, often exposed to extreme climatic changes, which they have frequently been noted to endure very successfully, should quickly and definitely respond to alterations in external conditions.

Oltmanns, ${ }^{3}$ however, does not cite any records of special adaptation to drought occurring in such terrestrial Algae as Pleurococcus, Hormidium, and Chlorella. Nor does the recent summary by Petersen ${ }^{4}$ of experiments on the power of various terrestrial Algae to withstand prolonged drought shed any light on the possible response of the Algae concerned to desiccation. On the other hand, Fritsch ${ }^{5}$ has recently observed various effects of drought in Zygnema evicetorum, notably the special peripheral disposition of its 'fat' globules. With a view to throwing further light on the adaptation of

1 From the Botanical Laboratory, East London College, University of London.

${ }^{2}$ F. E. Fritsch and F. Rich: Biology and Ecology of the Algal Flora of Abbut's Pool, near Bristol. Bristol Naturalists' Society's Proceedings, Fourth Series, vol. ii, part ii, 1909, p. 40; and $\mathrm{J}$. Comère : Observations sur la Périodicité du développement de la flore algologique dans la région toulousaine. Bull. Soc. Bot. de France, to liii, 1906, p. 399.

3 Oltmanns: Morphologie u. Biologie d. Algen, vol. ii, 1905, p. $35^{2}$.

- J. B. Petersen: Studier over Danske aërofile Alger. Mém. Ac. Roy. d. Sc. et d. Lettres d. Danemark, $7^{\mathrm{e}}$ sér., t. xii, I9I 5 , p. 353 .

B F. E. Fritsch: The Morphology and Ecology of an Extreme Terrestrial Form of Zygnema (Zygogonium) ericetorum (Kuetz.), Hansg. Ann. Bot., vol. xxx, I916, p. 143 et seq.

[Annals of Botany, Vol. XXXI. No5. CXXIII and CXXIV. July and October, 1917.] 
terrestrial Algae to their conditions of life, the present observations were made on a form of Hormidium flaccidum.

The results set out below relate to one form of this species occupying the bare stretches of a piece of grassland near a pond at Woodford, Epping Forest. The characteristic features of the Alga may be summarized as follows: The filaments normally consist of a single row of cells (Fig. I, A) and may be of considerable length (including sometimes as many as I,400 cells); their width varies between $9 \mu$ and $\mathrm{I} 3 \mu$, the average obtained from a large number of filaments being I I $\mu$. The lengths of the cells range from
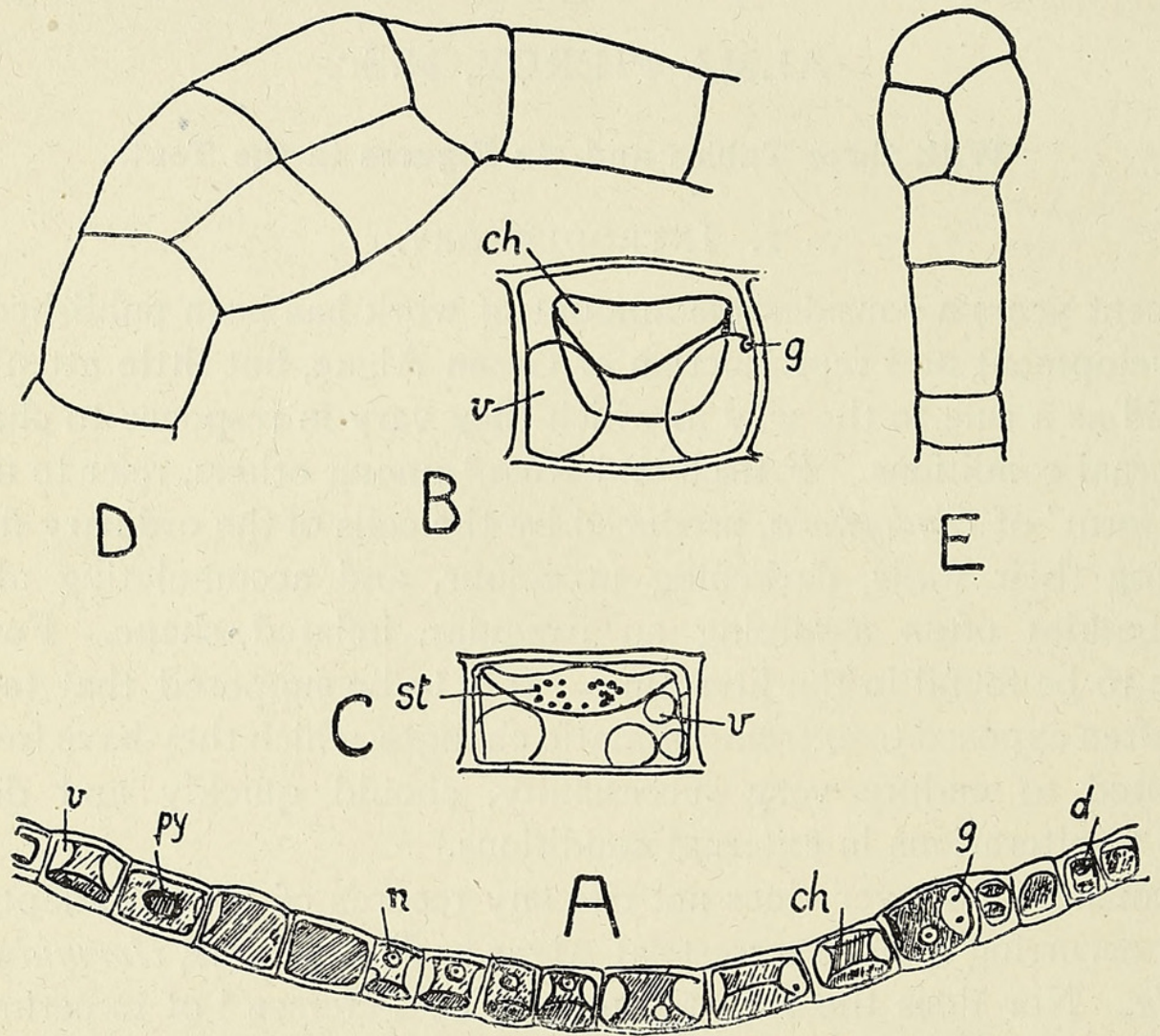

FIG. I. A, portion of a typical filament of the Woodford form of Hormidium faccidum growing on damp soil. B, cell containing two polar vacuoles. C, cell containing several small vacuoles in place of one of the polar vacuoles. D, E, parts of filaments showing abnormal cell-divisions. n., nucleus; ch., chloroplast; $p y$., pyrenoid; $v$., vacuole; st., starch ; $g$., granule; $d$., dead cell. $(\mathrm{A} \times 650 ; \mathrm{B} \times 2,000: \mathrm{C}, \mathrm{D} \times \mathrm{I}, 200 ; \mathrm{E} \times 850$.

two-thirds to two and a half times their width. A single plate-shaped chloroplast of a bright green colour lies just within the longitudinal wall of each cell, extending nearly the entire length and over about two-thirds of the circumference (Fig. I, A) ; one or both of its longitudinal edges have frequently a curved outline (Fig. I, C). The nucleus (Fig. I, A, n.) lies near to the longitudinal wall, usually between the two edges of the chloroplast. There are often two large vacuoles in each cell, extending a variable distance from the ends towards the middle (Fig. I, B, v.; Fig. 4, N); in short cells there is occasionally only one vacuole traversing the whole length of the cell. Numerous small vacuoles may replace the larger ones (Fig. I, C). 
Rarely, a cell becomes abnormally wide and subsequently divides by a longitudinal wall; two or three adjacent cells may behave in this manner (Fig. I, D and E). A filament has never been observed more than two cells wide in the abnormal part, but the longitudinal walls may arise somewhat irregularly.

It will be seen from the above that of the three forms of Hormidium flaccidum enumerated by Heering ${ }^{1}$ in his recent review, the Alga under consideration approaches the form aquatica, recorded as growing in stagnant water. It differs from the latter only in having a considerable proportion of short cells, of less length than breadth, and in habitat.

\section{MODE OF GROWTH.}

At Woodford, the Alga occurs in isolated patches, colonizing some large, bare tracts which interrupt the continuity of the grassland. These tracts were evidently overgrown by grass at some previous time, since a layer of grass roots and rhizomes is habitually present beneath the Hormidium layer. The whole area is low-lying, there being a pond and system of small streams in the immediate vicinity, which, no doubt, help to keep the soil relatively moist. The matting of grass remains, referred to above, also tends to keep the surface layer of Hormidium damp by preventing water from quickly penetrating the soil. The latter is relatively light and remains continuously damp during the winter, but becomes very dry during the hot summer months.

There is a certain competition between the grass and the Hormidium, especially at the junction of the two zones. The grass cannot endure for any considerable period the intense dry heat which occurs from time to time in midsummer, and soon withers. The Alga, however, is able to resist desiccation for a longer period, and on the return of wet weather resumes its normal growth. It then tends to occupy former grass areas. At the approach of spring, however, the grass fruits, lying in the meshes of the tangle of old stems and roots, germinate, and the new plants overgrow the surrounding Hormidium, which tends to die away: Thus the edge of the grassland once again establishes itself.

The Alga grows as a thin layer scarcely I $\mathrm{mm}$. thick over the surface of the ground. It is not definitely associated with the grass remains below, though occasional filaments grow downwards and then often coil round the latter. $^{2}$ Most of the threads, however, lie horizontally and interlace, producing a weft. The superficial filaments are much richer in the granules

1 W. Heering : Ulotrichales, Microsporales, Oedogoniales, in A. Pascher, Die Süsswasserflora Deutschlands, Österreichs und der Schweiz, Heft vi, I9I 4 , p. 46.

2 It may be noted that the filaments of another form of Hormidium flaccidum, found on the thin soil covering some stones in Victoria Park, appeared to bend down in a knee-like manner here and there into the soil ; the cells at the bends had usually lost their contents. 
and refractive masses, described below, than those beneath the surface of the stratum.

Under the varying influence of wetness and dryness, cold and heat, the Alga preserves its general features. It thrives at Woodford during the winter, when, as already described, the soil is continuously damp. Experiments have, moreover, shown that many cells can resist considerable desiccation during cold weather. The Hormidium is rarely subjected, in its native habitat, to abundant rainfall simultaneously with high summer temperature, but the combination of such conditions experimentally produced in a greenhouse tends to destroy it. The filaments, on the other hand, can resist a remarkably long period of desiccation during warm weather, though the resistance of individual cells varies considerably. The intense insolation which occurs in midsummer may, however, cause the death of a large

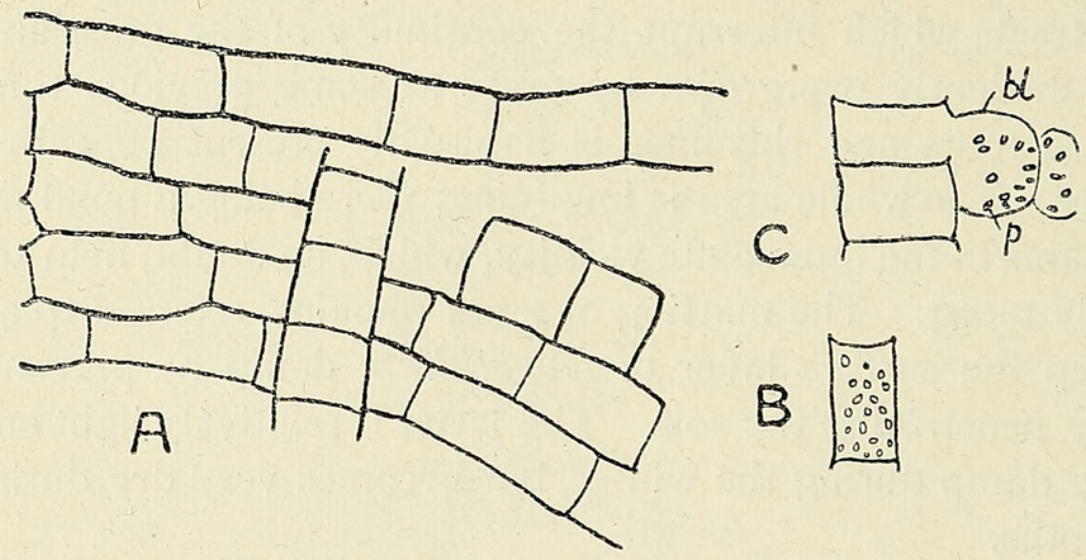

FIG. 2. A, false plate of cells formed by cohering filaments of Hormidium after drought。 $\mathbf{B}$, cell of a narrower form of Hormidium flaccidum infected by a parasite. C, shows escape of the parasitic organisms from the Hormidium cell. $p$., parasite; bl., enveloping vesicle. (A $\times 75^{\circ}$; B $\times I, 200 ; C \times I, 500$.)

proportion of cells even after a few weeks, the algal layer then assuming a general dark greyish colour.

Dry filaments retain the same form as wet ones, but become narrower to the extent of about $2 \mu$. On access of water turgor is instantaneously restored and the cell-cavities widen; if desiccation has been prolonged, there is frequently a visible swelling of the longitudinal wall ${ }^{1}{ }^{1}$ this seems to indicate a partially mucilaginous consistency. Neighbouring filaments, which usually cohere as plates or cords when dry (Fig. 2, A), move apart, and any existing curvature in a filament increases, unless it be due to hinging about a dead cell, in which case it decreases.

A close examination of filaments which have been subjected to desiccation shows that the latter produces definite changes in them. Some of the septa tend to become thickened so as to assume a biconcave form, ${ }^{2}$ as described

1 This was established by mounting the dry filaments first in alcohol and adding water subsequently.

2 A considerable amount of dew may be necessary during the period of drought to cause this development, as it is not produced by rigid desiccation. 
in detail below. Highly refractive granules and rounded masses generally accumulate in the cells (cf. p. 525), but the abundance and size of these depend on the food reserves available on the advent of drought, as well as on the degree of desiccation. Abundant starch is usually associated with the granules when numerous. A nother effect of prolonged drought is the frequent contraction of the chloroplast away from the cell wall, the protoplasm remaining in contact with the latter; the chloroplast also tends to become a yellowish green. When the temperature is high, the outer layer of the cell wall, the 'cuticle', ${ }^{1}$ cracks, and may become detached in small pieces.

In nature, Hormidium flaccidum may become infected by a parasite. This has not so far appeared in the Woodford Alga, but was found during the summer of 1915 in a form growing at Loughton, Epping Forest. Certain, usually scattered, cells were then observed to be filled with numerous minute ovoid organisms, which were perfectly colourless; the contents of the cells in question had either completely disappeared or become reduced to a thin peripheral vesicle often green in colour (Fig. 2, B). The cells of the parasite were frequently swarming, and would eventually escape through an aperture in the longitudinal wall (Fig. 2, C). They could subsequently be seen rotating about their longitudinal axis and swimming through the surrounding water. The organism is probably one of the Chytridiaceae, several of which are known to occur in the filaments of Ulotrichales. ${ }^{2}$

\section{Splitting.}

The splitting of the filaments at the transverse walls was recorded in Hormidium by A. Braun, ${ }^{3}$ and has subsequently been examined in $H$. dissectum (Ulothrix dissecta) by Gay, ${ }^{4}$ in $H$. nitens by Klebs, ${ }^{5}$ and in $H$. flaccidum by Gay, ${ }^{6}$ Klebs, ${ }^{7}$ and Borzi. ${ }^{8}$

In $H$. dissectum Gay observed the middle lamella of the septum to dissociate from the periphery inwards, fission resulting. The separation proceeded in an unsymmetrical manner, being more marked at one side of the filament than at the other, so that the two resulting fragments were inclined to each other. According to Gay, H. dissectum dissociates actively

1 This term, already adopted by Klebs and others, merely denotes the distinct, thin, external layer of the longitudinal wall. It has none of the characteristic properties of ordinary cuticle.

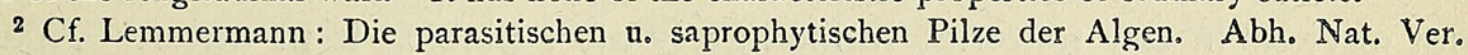
Bremen, xvii, I90I, p. 185 et seq.

3 A. Braun: Rejuvenescence in Nature, Leipzig, 1851. English translation by A. Henfrey, p. I3 I, foot-note.

- F. Gay : Recherches sur le Développement et la classification de quelques Algues vertes. Thèse, Paris, I891, p. 60.

5 G. Klebs : Bedingungen der Fortpflanzung, Jena, 1896, p. 329 et seq.

${ }^{6}$ 1. c., p. 63 . 7 1. c., p. 341 .

${ }^{3}$ Borzi : Studi algologici, fasc. ii, 1895 , pp. $361-9$. 
when kept damp. In the case of $H$. flaccidum he found splitting to be somewhat rare under normal terrestrial conditions, but more abundant when growth took place in water. Borzi states that splitting sets in after the filaments have attained a certain length, and that dissociation into individual cells occurs on the advent of dryness and when the Alga is cultivated on gelatine.

Klebs, ${ }^{1}$ working with $H$. nitens, found that splitting depended in no way on the number of divisions or the length of the threads. He states that it is occasional, mostly occurring at points of bending, when this Alga is cultivated in a solution of nutritive salts under conditions favourable to growth, but that a lack of nutritive salts, particularly nitrogen, phosphorus, and magnesium salts, or a lack of moisture causes a real breaking up of the threads into short few-celled pieces. He observed splitting in cultures on pure agar-agar. Regarding the direct cause of splitting, he suggests that on cessation of division thickening layers are no longer added to the cuticle connecting two adjacent cells; on the other hand, owing to the growth which goes on for some time and subsequently to the increase of turgor resulting from continued assimilation, the cuticle becomes stretched and ultimately tears. Thus the connexion between the cells is loosened here and there and the transverse septum then splits owing to the arching of its two constituent lamellae. In uniformity with Gay's ${ }^{2}$ observation, Klebs found that separation occurs more rapidly at one side of a septum than at the other, an angle being formed between the separating portions, while the filament as a whole takes on a zigzag form.

The process of splitting in the Woodford Hormidium agrees with that outlined for other forms by Gay and Klebs. There is never a complete dissociation into single cells, though, under certain conditions, a small proportion of the filaments break into few-celled pieces. Usually splitting is rather occasional, and the fragments are of considerable length.

The only condition which has been found effective in producing splitting is desiccation followed by an abundance of water. When, during a fortnight in summer, material kept in the greenhouse was only watered at intervals of two or three days, so that it became quite dry between successive supplies, many filaments dissociated into few-celled fragments. Other experiments have shown that splittings arise in material already subjected to desiccation for several weeks within a day or two after watering, but are not obvious in dry material immediately after placing it in water. Again, splittings were found to be common in filaments growing out of doors, which were examined on the second day following a spell of nine dry days. It is not probable that drought alone can produce splitting, as the latter did not appear during the desiccation experiments described below (p. 525).

To throw more light on the direct causes of splitting in this form of

$$
\text { 1. c., p. } 329 \text { et seq. }
$$$$
2 \text { 1. c., p. } 60 .
$$ 
Hormidium flaccidum, the parts affected, namely the longitudinal walls and the septa, were carefully examined. These investigations were made in the first place on material in which splitting had been abundantly produced by supplies of water alternating with periods of desiccation (p. $5^{16}$ ), and which had been subsequently kept without water for six weeks.

The longitudinal walls were relatively thin, but one could usually distinguish a 'cuticle' of variable thickness, though undergoing disintegration here and there, especially in the neighbourhood of the septa. In curved filaments the cuticle appeared folded or corrugated along the concave surface of the bend (Fig. 3, A). Occasionally isolated bulbous thickenings were deposited on the inner surface of the longitudinal wall, while in dead cells a definite, though irregular, inner layer was frequent. The septa were commonly biconcave owing to the two component lamellae diverging before merging into the longitudinal wall, the region between them being occupied by a substance of different refractive index (Fig. 3, B). The latter often extended right across the septum so as to separate completely the two lamellae, and had occasionally become drawn out in the longitudinal direction so as to form a short cord connecting the two adjacent cells (Fig. 3, C, m.). Even when the thickening was much less pronounced the filaments were often slightly constricted in the regions of the thickened septa.

Thickened biconcave septa have been observed in desiccated material growing naturally out of doors in cold and warm weather. In such cases, however, the amount of damping produced by dew during the time of drought, as well as the exact external conditions preceding it, have not been properly known. The fact that thickenings did not appear in material subjected to continuous desiccation during many weeks when the dew was inconsiderable (cf. Desiccation Experiment I, p. 525) seems to indicate that drought is not the entire cause of this particular thickening of the septa. There may be a certain amount of intermittent moisture required, and possibly individual peculiarities of adjacent cells have some additional influence, as is suggested by the fact that septa in the same filament exhibit a great deal of variation in the degree of thickening, many remaining unthickened while others are considerably thickened.

Some indication of the chemical nature of the longitudinal walls and septa was sought by treatment of the above-mentioned material with various reagents and stains. Walls and septa were completely dissolved by concentrated sulphuric acid. Ordinary iodine solution, added to fresh filaments, caused the 'cuticle' to become very distinct as a dark line, which was thinner opposite the septa, the disintegrated portions staining blue. The remainder of the longitudinal wall, as well as the septa, assumed a pale blue colour. Methylene blue stained the disintegrating parts of the 'cuticle' (Fig. $3, \mathrm{D}$ ) and the débris of thickening substance often associated with 
splitting septa; occasionally, the entire remaining portion of a partially split septum became blue, but usually, with these and intact septa, only a restricted area of the thickening substance within the fork of the lamellae was affected.
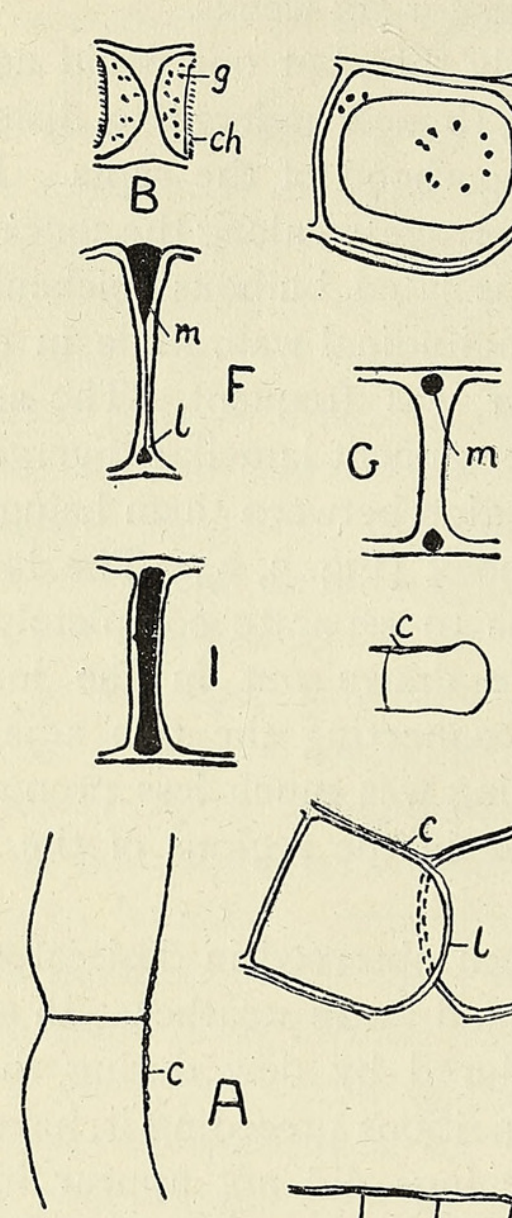

C
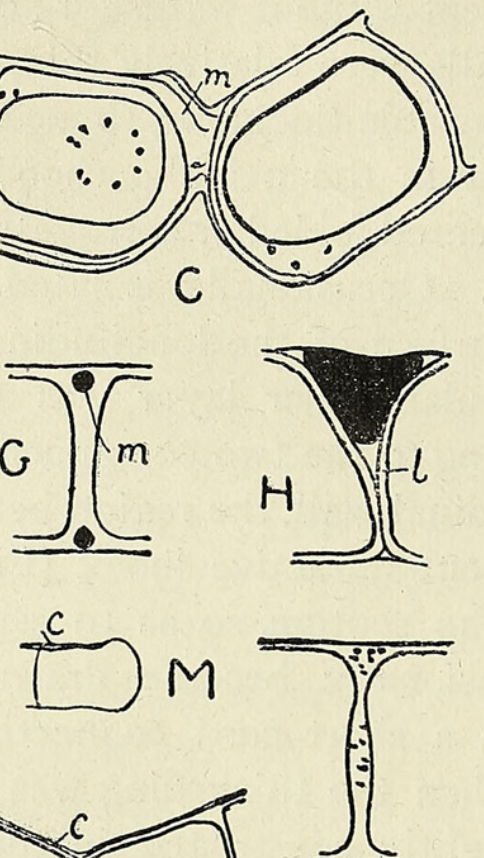

$\mathrm{J}$
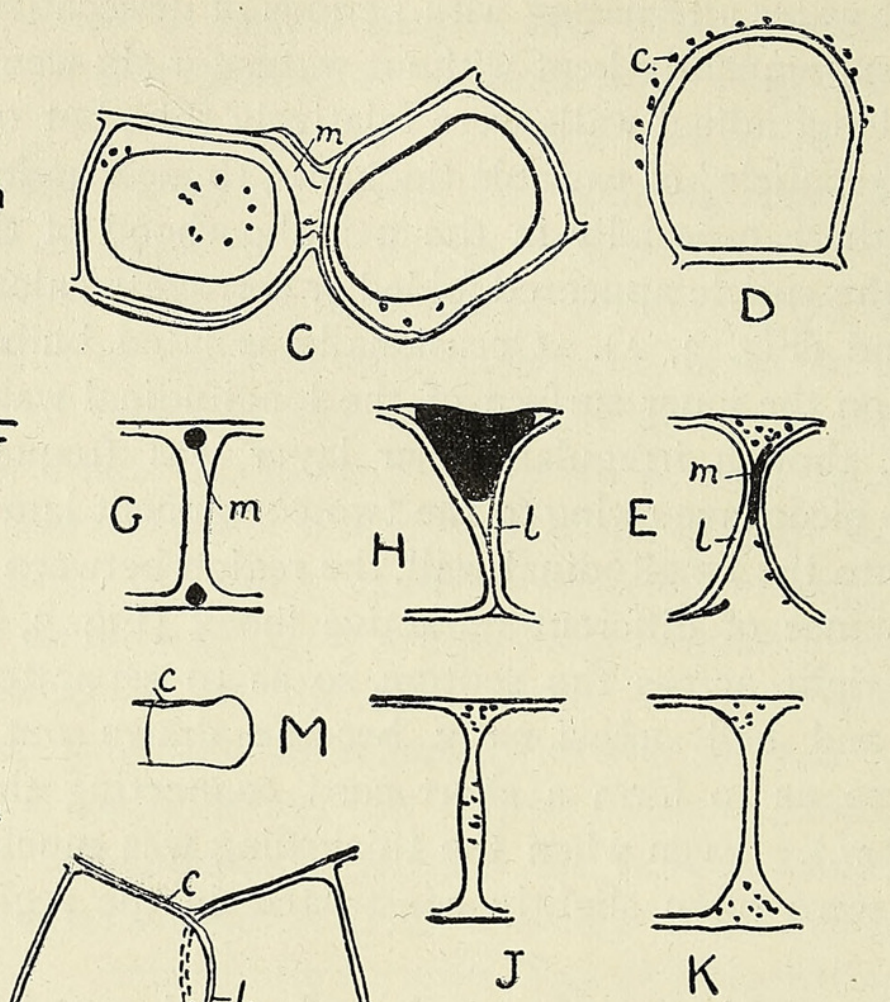

D
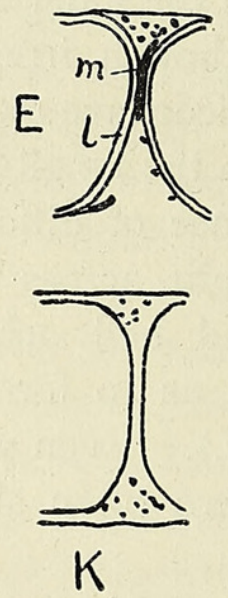

$N$

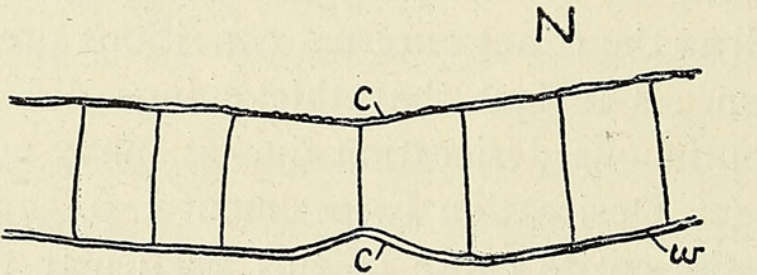

FIG. 3. A, bend in a filament, causing 'cuticle' at the concave surface to become corrugated. $\mathrm{B}$, biconcave septum in optical section. C, thickening substance of septum drawn out between two cells. D, disintegrating 'cuticle' stained by methylene blue. E-I, septa stained by Ehrlich's haematoxylin, in optical section; E, F, splitting septa in which the middle layer of the intact part and the débris of thickening substance adhering to the dissociated part have taken up the stain; G, shows stained area within fork of the lamellae of the septum; H, shows stained thickening substance in a drawn-out septum. I, entire middle layer of an intact septum stained. J, K, septa from filaments growing in nutritive solutions stained with Ehrlich's haematoxylin. L, septum in which splitting is nearly accomplished. $M$, cell recently detached by splitting of filament, widened at its free extremity. $\mathrm{N}$, curved filament which has contracted on becoming dry, showing the 'cuticle' dissociated from longitudinal wall on convex surface, and corrugated on the concave surface of bend. c., 'cuticle'; $m$., thickening substance of septum; l., lamellae of septum; $w$., longitudinal wall; ; other lettering as in Fig. I. (A, B $\times 890 ; \mathrm{C}-\mathrm{K} \times \mathrm{I}, 500 ; \mathrm{L} \times \mathrm{I}, 300 ; \mathrm{M} \times 480 ; \mathrm{N} \times \mathrm{I}, \mathrm{I} 50$.)

The longitudinal walls remained unstained. Treatment with Ehrlich's haematoxylin for about seven minutes, and rapid rinsing in water subsequently, produced results (Fig. 3, E and F) similar to those obtained with methylene blue, the longitudinal walls as a whole being still unstained, though the cell-contents had become deeply coloured, while usually the 
same localized region of thickening substance within the fork of the lamellae of the septum became deep purple, and could be traced as a continuous girdle round the filament, embedded in the septum some little distance within the 'cuticle' (Fig. 3, G). The stained substance appeared in great bulk in drawn-out septa (Fig. 3, H). When splitting was in progress, as well as occasionally in intact septa, the whole middle portion of the septum, between two unstained lamellae, became deeply coloured (Fig. 3, E and I). A débris of stained particles was occasionally seen in contact with the new end cells of pieces of filament recently detached.

The results produced by the above stains show that in the material examined the cuticle was somewhat mucilaginous, especially where obviously disintegrated. The thickening substance in the septa was usually mucilaginous near the periphery, and in certain cases formed a continuous plate of mucilaginous material through the middle of the septum. Also, mucilaginous substance was generally associated with the separating lamellae of splitting septa.

For comparison, similar observations were made on material which had been growing for some weeks in rutritive solution and showed no indication of splitting. Here the 'cuticle' of the longitudinal walls was not distinguishable except opposite the septa, and there was no degeneration. The two distinct lamellae of the septa were often apparent, diverging a little before joining the longitudinal wall and often dissociated to a small extent in the central region, thus rendering the septum slightly biconvex (Fig. 3, J). There was always a thickening substance between the two lamellae, but this did not respond to methylene blue and Ehrlich's haematoxylin so readily as that in the material examined above. With both these stains, only small particles within the fork at the edge of the septum and scattered in the thickening of the central region became coloured (Fig. $3, \mathrm{~J}, \mathrm{~K}$ ).

From the preceding data the following conclusions may be drawn: The 'cuticle' tends to undergo a certain mucilaginous degeneration and to become especially thin opposite the septa. There is normally secreted in thickening septa a mucilaginous substance, which may form a continuous layer throughout the septa. This substance is very generally associated with splitting septa and frequently with the end wall of newly separated pieces of filament.

An examination of partially split septa, which were numerous in the material described on p. 527 , furnished the following details regarding the process of splitting. The latter was usually initiated by the disintegration of the 'cuticle' at a septum, but sometimes the lamellae of the latter first separated at their edges, and the 'cuticle' adapted itself to the new shape by stretching, until it ultimately broke across. Partial splittings were common in bent filaments, being restricted to the portions of the septa on . the outside of the curve. They were, however, occasionally present in 
straight filaments, and were then noted to occur usually between cells which contracted at different rates on loss of water; in these cases, too, they affected the entire circumference of the septum, without extending right across it. As the lamellae of a septum were gradually separated by the breaking down of the thickening substance between them, they became bulged in a convex manner as is usual with free end walls (Fig. 3, L).

Attempts to produce splittings by wetting dry filaments under the microscope, and to extend partial splittings by successively drying and wetting the filaments, were unsuccessful. The latter treatment, nevertheless, caused a swinging movement in curved filaments, and probably, where the rate of contraction was different in adjacent cells, a definite strain on the cuticle at the transverse walls. Dry filaments were, however, observed to shear at septa adjacent to dead cells, on becoming suddenly turgescent.

In a consideration of the causes of splitting, the 'cuticle' may be treated as a thin cylindrical shell subject to internal fluid pressure. This assumption appears to be warranted by the observation that cells separated by a split often widen at their free extremities (Fig. 3, M), where the 'cuticular' sheath has given way, this indicating that the latter constitutes a distinct strengthening layer of the wall. 'The 'cuticle' should therefore be especially capable of resisting a transverse tear. ${ }^{1}$ When a filament is bent, a greater longitudinal stress is set up in the 'cuticle' at the outside of the curve, but splitting occurs also in straight filaments and then begins round the whole circumference of the filament. It would therefore seem that splitting at a septum, if occasioned by increase of turgor as described by Klebs, can only arise where there is a general or local weakening of the 'cuticle' at the septa. It has been shown above that a more or less general degeneration of the 'cuticle', frequently pronounced at the septa, does occur in filaments which are in process of splitting. Such a degeneration probably results from the folding and stretching of the 'cuticle' caused by curvature of the filaments, and from the separation of the 'cuticle' from the longitudinal wall, occasionally observed when a filament contracts owing to loss of water (Fig. 3, N). One reason for its prevalence in the regions of the septa may be the difference in the rate of contraction and possibly expansion, occurring among individual cells of the same filament, during changes in turgescence. On the other hand, splitting might result from a distinct longitudinal force being brought into play between the two lamellae of the septum, tending to separate them. A special weakening of the 'cuticle' adjacent to the septa must be produced by the development of the mucilaginous substance, and the continued extension of this substance possibly produces a longitudinal force which ultimately ruptures the 'cuticle'.

1 The resistance of such a cylindrical shell to a transverse tear is double its resistance to a. longitudinal tear. Cf. D. A. Low : Applied Mechanics, p. 76. 


\section{Aplanospores.}

As appears in other sections of this paper, the Woodford form of Hormidium flaccidum has been grown under many different external conditions. Yet, apart from splitting, the only method of reproduction observed was the formation of aplanospores. The treatment by which

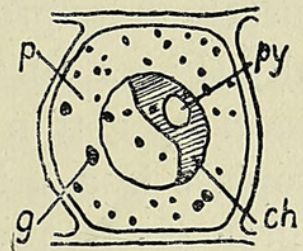

A

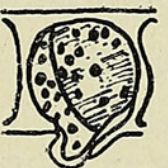

F

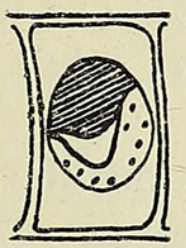

D

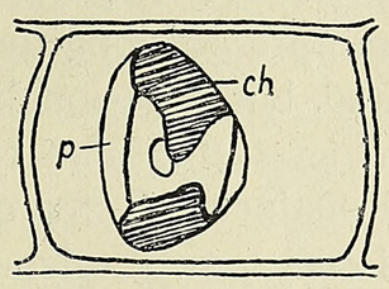

B

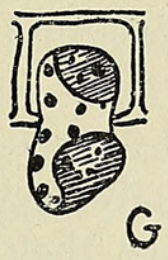

G

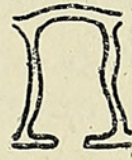

H

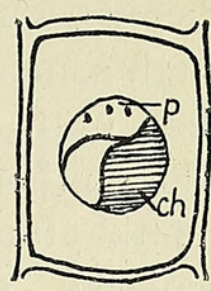

C

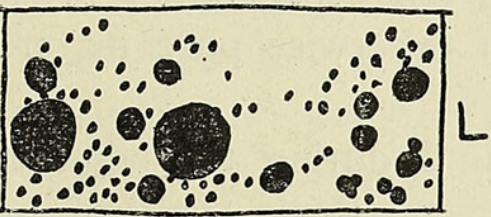

E
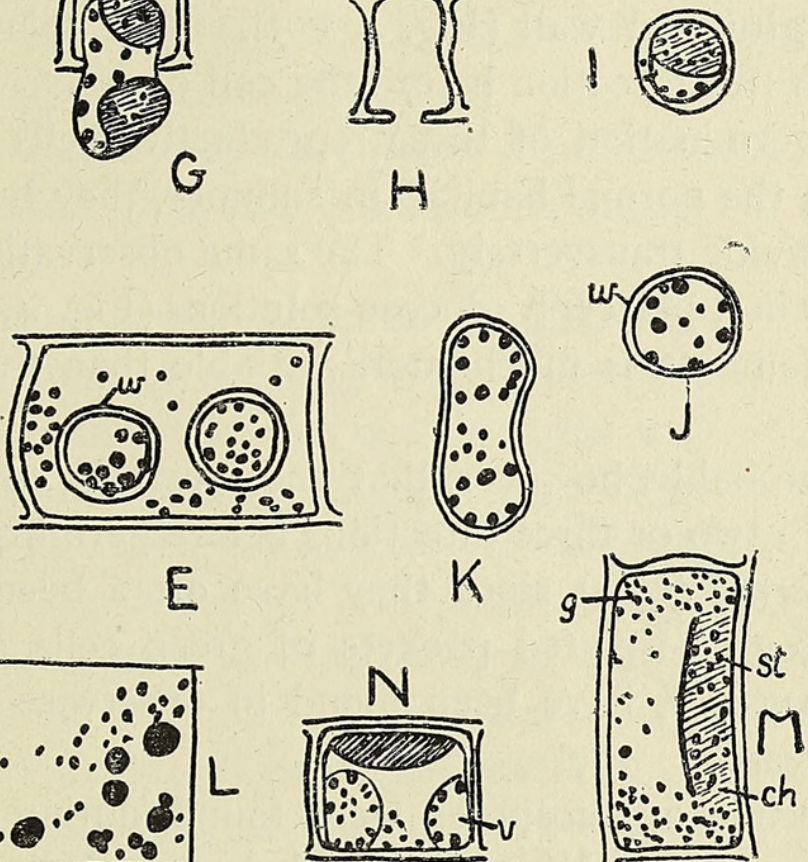

FIG. 4. A-K, stages in the production of free aplanospores. A, contraction of chloroplast to centre of cell. B, C, D, protoplasm contracted round chloroplast. E, development of surrounding membrane before liberation. F, G, liberation of aplanospore. H, empty parent cell, with aperture in wall. I, free aplanospore. J, aplanospore with surrounding wall. $\mathrm{K}$, first stage in germination. $\mathrm{L}$, cell showing distribution of refractive granules and masses in superficial protoplasm. $\mathrm{M}$, customary distribution of granules, when numerous. $\mathbf{N}$, granules arising in the vacuoles. p., protoplasm; w., cell membrane; other lettering as in Fig. I. (A, B, D $\times 1,750 ; \mathrm{C}, \mathrm{E} \times \mathrm{I}, 360 ; \mathrm{F}-\mathrm{K}, \mathrm{N} \times 900$; $\mathrm{L} \times \mathrm{I}, 500 ; \mathrm{M} \times \mathrm{I}, 000)$.

Klebs ${ }^{1}$ obtained zoospores in another form of $H$. flaccidum, viz. transference of threads from a nutritive solution into water in darkness, has not proved successful with this form.

The aplanospores of $\mathrm{H}$. flaccidum have only been described in forma typica, where they are rounded and have a spinous wall resembling a

$$
\begin{gathered}
{ }^{1} \text { 1. c., p. } 343 . \\
\text { N } n
\end{gathered}
$$


Trochiscia. ${ }^{1}$ The formation and liberation of aplanospores in the Woodford form takes place as follows: The chloroplast contracts and comes to lie in the centre of the cell (Fig. 4, A). Then the protoplasm retreats from the cell wall and closely envelops the chloroplast (Fig. 4, B, C). In cells containing granules, a certain number may be extruded during this process. The resulting aplanospore is generally slightly oval in shape, its average dimensions being $9 \mu$ by $8 \mu$; in short cells it is frequently more pronouncedly oval, as though somewhat compressed longitudinally (Fig. 4, D). It usually remains naked until liberated, but occasionally develops a thin wall while still within the mother-cell (Fig. 4, E). The chloroplast is a bright green, and the pyrenoid often very distinct. Refractive granules frequently occur in the protoplasm. Occasionally, two aplanospores arise within a single cell (Fig. 4, E).

The aplanospore is liberated by the rupture of a papilla, which develops in the longitudinal wall (Fig. $4, \mathrm{~F}-\mathrm{I}$ ). The aplanospore is often seen to protrude in this direction before the cell opens.

The germination of these reproductive cells has not been followed in detail. In the normal habitat, in summer, they have been seen to elongate and then divide transversely. The same observation was made more rarely in cultures in 5 per cent. glucose solutions (Fig. $4, \mathrm{~K}$ ). The width of such juvenile filaments is much more variable than that of adult ones, usually being less.

It is probable, however, that under certain conditions the aplanospores subdivide in two or three directions before germinating, after the manner of those of forma typica, since they have often been observed in pairs when free. Moreover, isolated packets of green cells, similar in size though of obscure structure, have been found in otherwise pure material producing aplanospores.

Many free aplanospores were found during the summer of 1916 in material growing at Woodford, and during three weeks of sunshine in the summer of 1915 (average daily range of temperature $53^{\circ} \mathrm{F} .83^{\circ} \mathrm{F}$.) in material growing in 2 per cent. to 5 per cent. glucose solutions. They have also appeared, though not in abundance, during damp winter weather. A planospores are not formed under conditions of drought; nevertheless, they can evidently resist considerable desiccation, since they were found to survive a dry period lasting one month, at low temperature (average range $3 \mathrm{I}^{\circ}-5 \mathrm{I}^{\circ} \mathrm{F}$.), and a short period of severe desiccation in midsummer.

\section{Cell-Contents.}

Under certain conditions well-defined, white, refractive granules become conspicuous in the cell-contents of this Hormidium. These granules are.

1 Cf. Heering, l. c. , p. 46, Fig. 49. 
more or less spherical in form, though tending to assume an irregular shape when large. They vary considerably in size, being often scarcely visible under a magnification of 3,000 and passing through all gradations to a diameter of about $4 \mu$ (Fig. $4, \mathrm{~L}$ ). When present only in small numbers, they lie here and there in the surface layer of the protoplasm, most commonly near the septa. If exceedingly abundant, they are concentrated at the ends of the cells, but may also be numerous in the part of the protoplasm between the two longitudinal edges of the chloroplast (Fig. 4, M) ; occasional granules are always scattered in the surface protoplasm adjacent to the chloroplast. During the earlier stages of accumulation, the cells are usually vacuolar, as described above (p. $5^{\mathrm{I} 2}$ ), and the first-formed granules appear mostly at the surface of the vacuoles (Fig. 4, N). In the later stages, the masses of granules at the ends of the cells frequently preserve the outlines of the vacuoles and can be seen to have entirely occupied the latter. This suggests that they are produced as a result of changes occurring chiefly in the contents of the vacuoles (cf. p. 532).

Granules similar in appearance have been found in other forms ${ }^{1}$ of Hormidium flaccidum distinct from the Woodford Alga, and in Spirogyra, ${ }^{2}$ Prasiola, and Pleurococcus.

Gay $^{3}$ has recorded the accumulation of oil globules in Hormidium dissectum (Ulothrix dissecta) when growing in water, and Klebs ${ }^{4}$ has stated with reference to $H$. nitens that the cells become filled with drops of fatty oil when subjected to slow desiccation. Klercker, ${ }^{5}$ in Stichococcus subtilis, described droplets, which he called 'spherules', usually present in the polar vacuoles, ${ }^{6}$ but sometimes 'accumulating in such abundance as to make an examination of the internal structure of the cell almost impossible'. Apart from their similar disposition in the cells, these bear a striking resemblance, as shown in the figures, to the granules of Hormidium. Klercker ${ }^{7}$ states that they agree in many respects with the substances occurring in Stigeoclonium and other Chaetophoraceae. The globules of Zygnema ericetorum described by Fritsch, ${ }^{8}$ West and Starkey, ${ }^{9}$ and de Bary ${ }^{10}$ are somewhat similar in form and appearance to those of Hormidium flaccidum and

1 Viz. (i) a narrower form, with filaments of average width $5^{\circ} 7 \mu$, growing at Loughton, Epping Forest; (ii) a wider form growing on Hindhead Common. I have to thank Dr. Fritsch for the information regarding this Alga, and for material.

2 Probably tannin-vesicles. Cf. Czapek: Biochemie der Pflanzen, vol. ii, I905, p. 579; Hill and Haas: The Chemistry of Plant Products, 1912, p. 191. They take on a brown coloration with osmic acid similar to that produced by the latter in the granules of Hormidium.

3 1. c., p. 62 . 4 1. c., p. 340.

5 Klercker : Ueber zwei Wasserformen von Stichococcus. Flora, vol. 1xxxii, I896, pp. 92, 93.

6 These resemble, in form and disposition, the vacuoles of the Alga dealt with in this paper.

7 1. c., p. 92. 8 F. E. Fritsch, l. c., p. I43.

9 G. S. West and C. B. Starkey : A Contribution to the Cytology and Life-history of Zygnema ericetorum (Kuetz.), Hansg. New Phytol., vol. xiv, I9I5, p. I97.

10 de Bary: Unters. über die Familie der Conjugaten, Leipzig, I858, p. Io, Pl. I, Figs. 16, 20. 
Stichococcus subtilis; in the Zygnema, however, they commonly occur distributed in the whole peripheral layer of the protoplasm.

The refractive bodies of the Zygnemaceae (Zygnema and Spirogyra) have been referred to variously as tannin-vesicles ${ }^{1}$ and fat-bodies. ${ }^{2}$ According to Klercker, ${ }^{3}$ those of Stichococcus subtilis have been constantly recorded as 'oil', but fail to show any distinct fat-reactions. As in the case of Stigeoclonium, he succeeded in staining them with Bismarck brown and aniline dyes, without killing the cells.

The frequent occurrence of white refractive granules in the cells of many different Algae suggests that there may be some product, common to their metatobic processes, which assumes this form under certain conditions. Such a view could only be corroborated by a large amount of experimental work, but the similarity in the appearance of the different granules and in their behaviour towards reagents, ${ }^{4}$ as well as their accumulation under like conditions, ${ }^{5}$ may indicate some such fundamental relationship between them.

The granules found in the Woodford Hormidium do not appear to be of the nature of ordinary fat, since they fail to dissolve in the usual fatsolvents (e.g. ether, benzole, carbon bisulphide) and are not saponified by treatment with a mixture of concentrated ammonia and caustic potash. ${ }^{6}$ On the other hand, osmic acid stains them brown, though never black, and Sharlach $\mathrm{R}$ colours them light red, but not deep red as in the case of fats. They retain their form after treatment with boiling water.

Apart from the above, the granules show the following chemical properties: They are insoluble in concentrated sulphuric acid; are unstained by iodine ; coloured green by chlorophyll, ${ }^{7}$ and reddish-brown by a solution of iodine in potassium iodide with subsequent addition of dilute sulphuric acid. ${ }^{8}$ These reactions, besides those with osmic acid and Sharlach R, are all more particularly characteristic of cuticle, and would appear to indicate that the granules are composed of some fat-like substance similar to that occurring in a cuticularized wall. ${ }^{9}$

In the case of large granules or masses, the interior appears to stain more deeply than the peripheral layer when the above reagents are applied. This differentiation is marked on staining with methylene blue, ${ }^{10}$ the interior

1 Van Wisselingh : Koninkl. Akad. v. Wetensch., Amsterdam, I9Io.

2 Cf. de Bary, 1.c., p. Io; West and Starkey, 1.c., p. I98, and Zimmermann, Botanical Microtechnique English translation by J. E. Humphrey, I893, p. 234.

s l. c., p. 93.

4 This is not quite the same, however, in all cases. Cf. Fritsch, 1. c., p. I44.

${ }^{5}$ Cf. Fritsch, 1.c., p. 143, and Klercker, 1. c., p. 94.

${ }^{6}$ Cf. Zimmermann, 1. c., p. 73.

7 When cells are heated in water or placed in alcohol, the granules absorb the chlorophyll from the chloroplast. The localization of chlorophyll which results is very noticeable, especially as it does not occur in non-granular cells present in the same filaments.

8 As described by Strasburger: Practical Botany, English translation by W. Hillhouse, pp. 47 and 395 .

9 Cf Zimmermann, l. c., p. I 52 .

10 Recorded as a stain for fat by Lee: The Microtomist's Vade Mecum, 1893, 3rd ed., p. 80. 
of the granule assuming a deep blue colour, while the thin external layer becomes merely light blue. The fact that the outer portion of the granules behaves rather differently from the interior towards reagents indicates that the structure of the granules is possibly vesicular, the contained substance differing somewhat from the bounding layer. Such a structure would be .comparable to that recorded for the granules of $Z$ ygnemaceae (cf. p. 523).

Commenting on the special abundance of granules in a heath form of Zygnema evicetorum, and their formation into a dense peripheral layer in time of drought, Fritsch ${ }^{1}$ observes that one might be disposed to associate the granular layer with the great power of resistance to drought possessed by this Alga. The question appeared of some importance in connexion with Hormidium flaccidum, which, though capable of considerable resistance to desiccation, shows none of the usual xerophytic adaptations, e.g. thick mucilaginous walls. Since granules are not habitually present in the cells, general observations were made to trace some relationship between desiccation and the appearance of granules, and also to reveal the power of resistance to drought possessed by granular material.

As a result, it was found that during periods of desiccation, both in summer and winter, granules always occurred in a large proportion of the living cells, but were frequently minute and scanty. When the Alga was receiving continuous supplies of water, the granules were sometimes prevalent in the cells, at other times localized in a small proportion of them. The latter variation apparently depended on the temperature and amount of sunshine. During winter, when the soil was continuously damp, the granules were often entirely absent, and, when present, were usually small and restricted to a minor proportion of the cells $(25$ per cent. and 46 per cent. in different samples collected in mid-winter). During warm, sunny weather, ${ }^{2}$ they appeared in most of the cells, and were both large and abundant. These observations indicated that granules do arise as a result of desiccation, though at such times they may be small and scanty; but they also appear, often in abundance, under other circumstances, viz. warm, damp sunny weather.

To observe more accurately the resistance of the cells to drought and the effect of the latter in producing granules, experiments were set up to subject the Alga to continuous drought, the other conditions of growth being so far as possible untouched. A large patch of Hormidium, with a considerable thickness of underlying soil, was collected from the native habitat and examined at frequent intervals during the experiment.

In Experiment I, which lasted from the end of January to the middle of March, the piece of soil was laid on a glass Petri dish and kept out of

1 1. c., p. I 45 .

2 Observations were made on material transplanted, with considerable depth of underlying soil, to a greenhouse. 


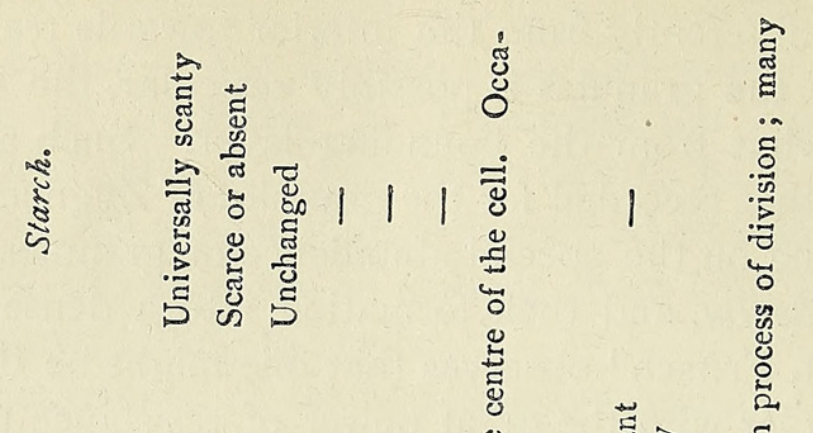

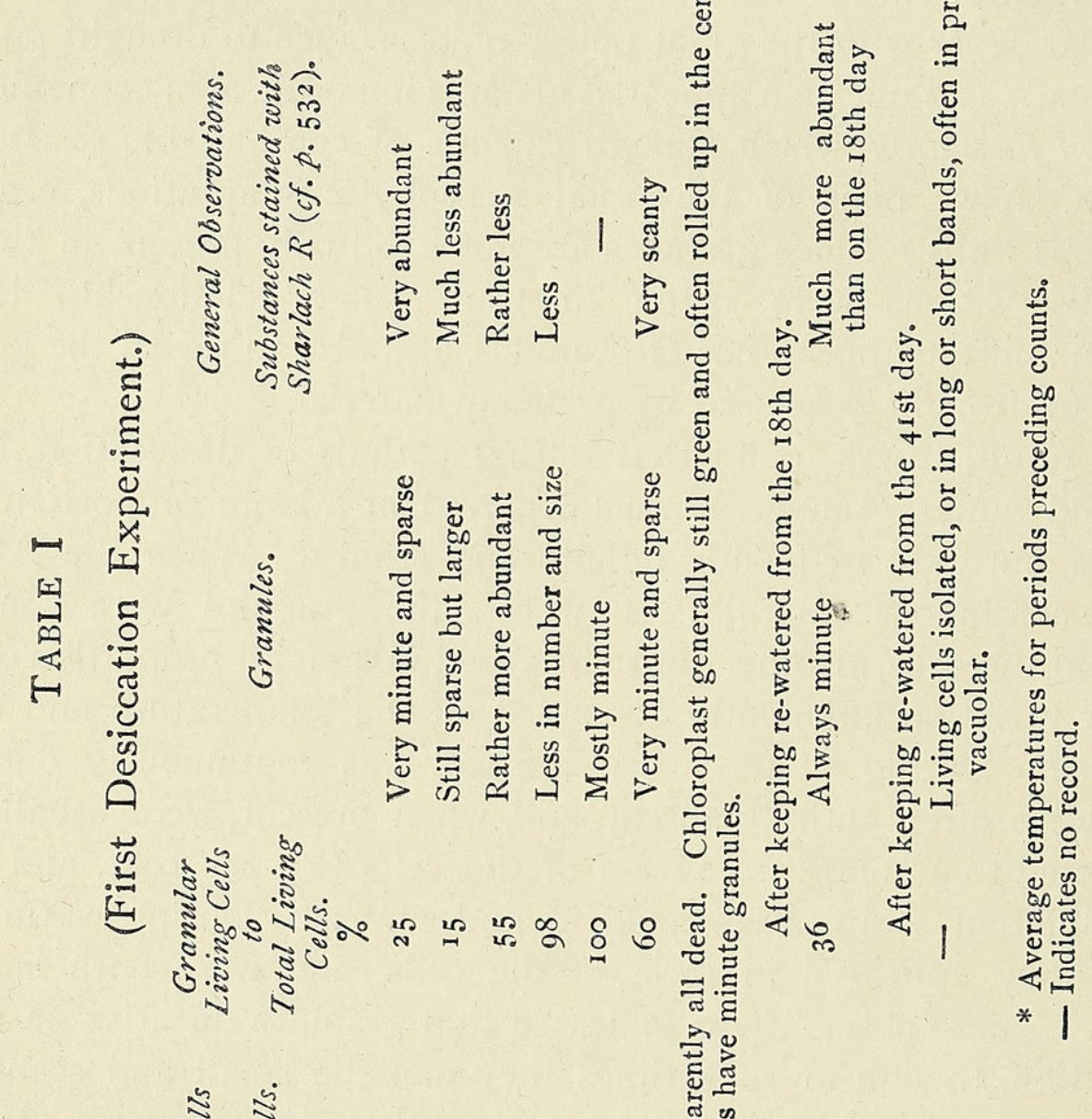

$$
\begin{aligned}
& \text { ป⿱艹 }
\end{aligned}
$$

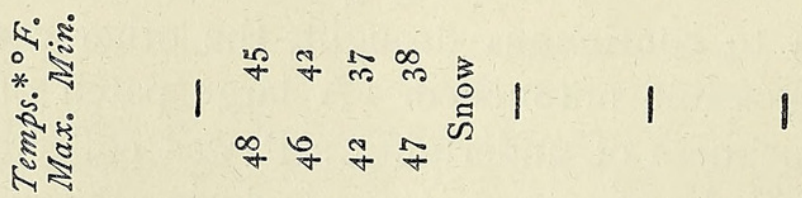

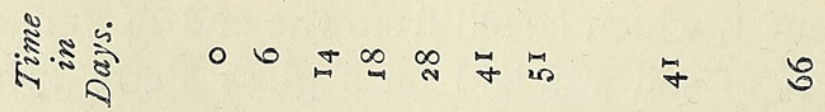


<smiles>CC(C)CC(C)C</smiles>

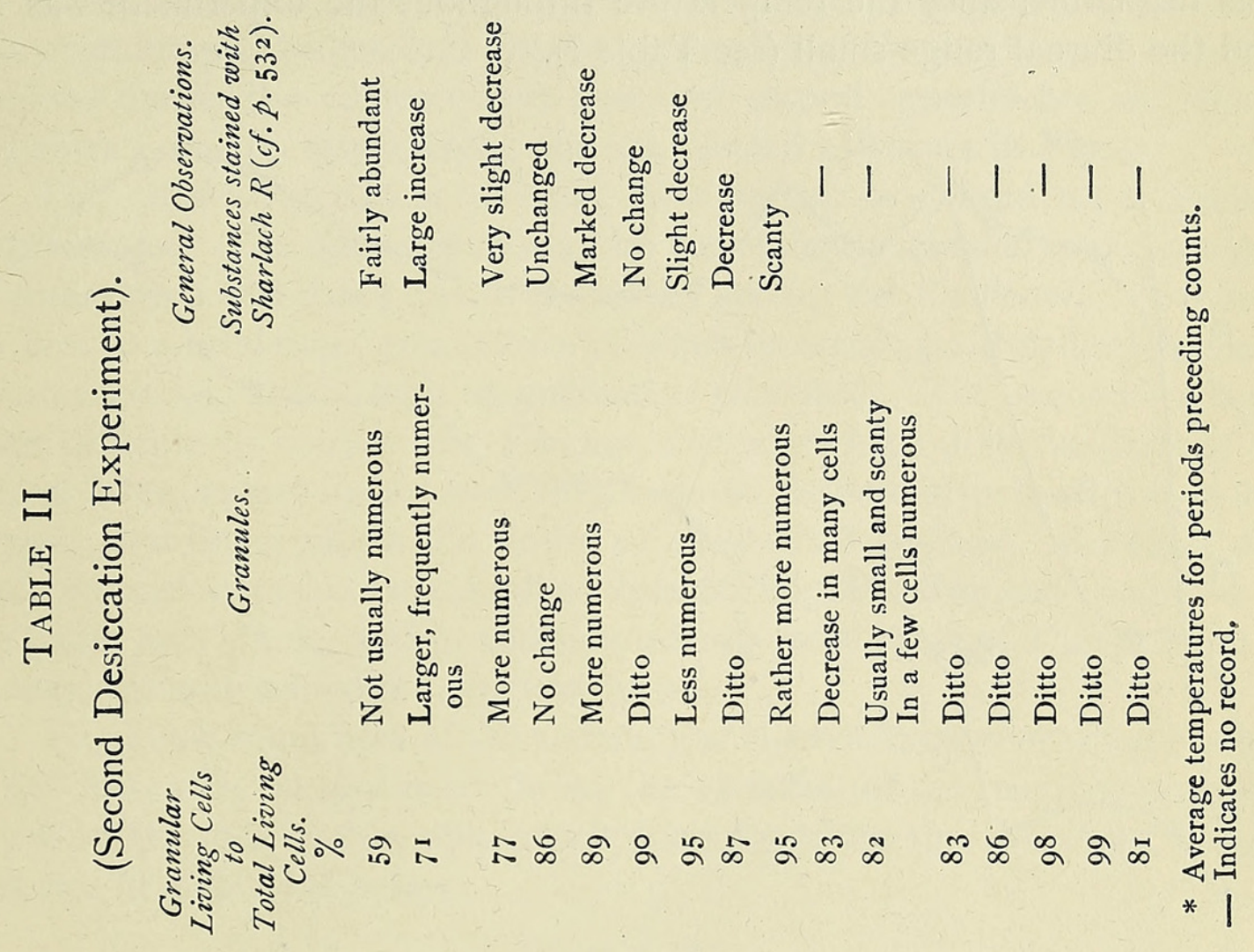

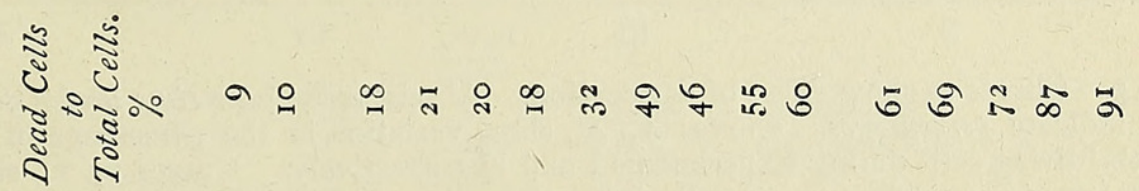

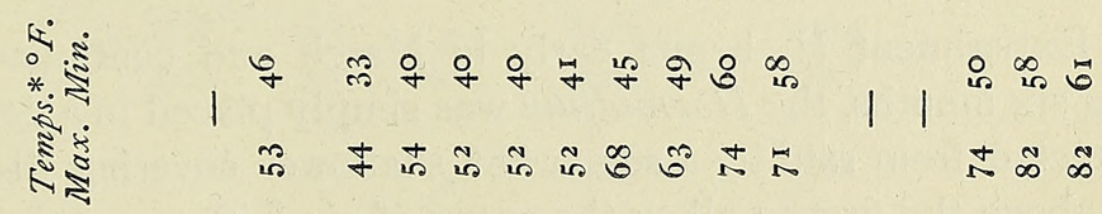

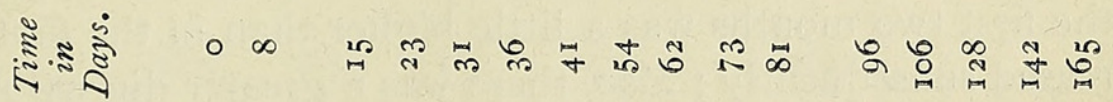


doors under a large bell-jar. The dish containing the Hormidium rested on an inverted seed-pan having several large holes in its base. To allow the passage of air through the apparatus, the seed-pan was supported on two bricks, and a glass tube was led into the top of the bell-jar through a rubber cork. The tube was bent into two right angles, the free end being long and directed downwards. Thus, when the rubber cork had been thoroughly covered with vaseline and the bell-jar cemented to the seed-pan, the entry of rain was prevented. The bell-jar was weighted down to resist the wind.

The deposit of dew which might have occurred under these circumstances was negligible, since the temperature throughout the experiment was low and the diurnal range small (see Table I).

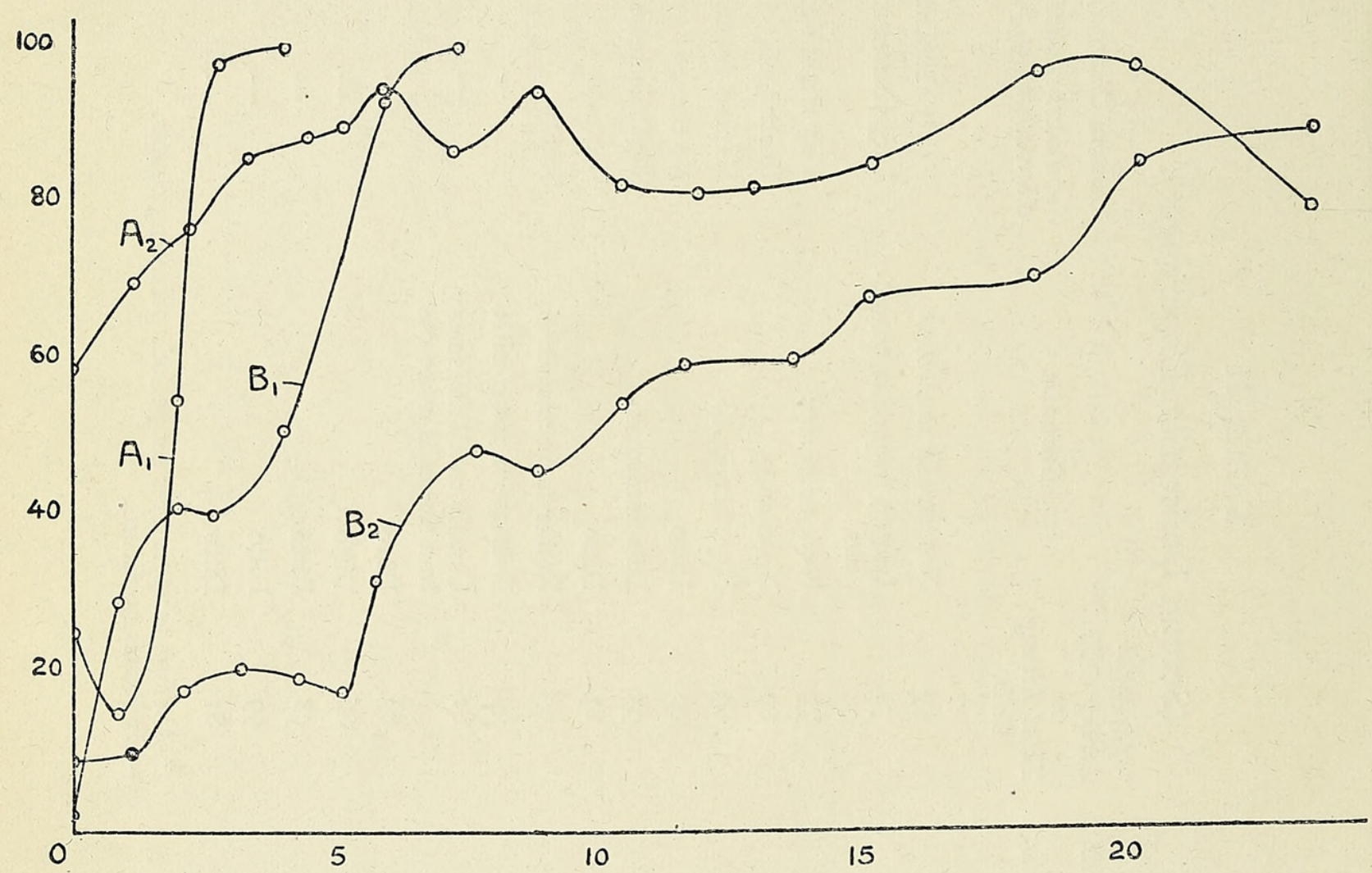

FIG. 5. Curves to show effect of desiccation. Abscissae indicate time under drought in weeks, ordinates indicate percentages. Curves $\mathrm{A}_{1}, \mathrm{~A}_{2}$, show variation in the percentage of granular living cells to total living cells during Experiments I and II respectively. Curves $\mathrm{B}_{1}, \mathrm{~B}_{2}$, show variation in the percentage of dead cells to total cells during Experiments I and II respectively (cf. pp. 526,527$)$.

In Experiment II, begun early in March and continued during the following six months, the Hormidium was simply placed in a deep glass bowl and protected from rain by a somewhat shallower covering dish, supported slightly above the first to allow the entry of air. The average temperature during the first two months was a little higher than in the first experiment, and increased subsequently; also, there was a greater diurnal range of temperature, especially during the last weeks of the experiment (see Table II).

These conditions of temperature tended to cause a greater deposit of dew than occurred during Experiment I, as did also the prevalence of much 
less draught through the apparatus of the second experiment than through that of the first experiment. Direct evidence of the abundant humidity of the air inside the glass bowl was furnished by the condensation of drops of water on the inside of the covering glass during the first two or three weeks of this experiment. The process of desiccation to which the Hormidium was subjected in Experiment II was therefore much more gradual than in Experiment I, and this was shown by the soil remaining obviously damp during the first fortnight.

At intervals of about a week, the size and frequency of the granules in the cells were noted and records made of (i) the proportion of the living cells containing granules, and (ii) the proportion of dead cells. The results obtained during the course of the first and second experiments are shown in Tables I and II, respectively, and are plotted as curves in Fig. 5.

The question arises as to what reliance can be placed on individual observations. The chief errors may be conveniently divided into those due to observation and those due to variability among the filaments. To reduce the first to a minimum, great care was taken to secure good definition under the microscope, and a high magnification was used. The second were far more difficult to cope with. Filaments selected from different parts of an area of a few square inches were very variable, as were also, though to a less degree, even those within the limits of very small regions. An effort was made on each occasion to examine filaments representing the condition of the patch as a whole, and in addition records were made of a large number of cells; usually between 2,000 and 3,000 .

To obtain some idea of the accuracy of the readings, counts were made, in two instances, on successive days ; the variation of the readings on either day from the mean value, obtained by compounding the two days' counts, is shown in Table III below:

\section{TABLE III}

Dead

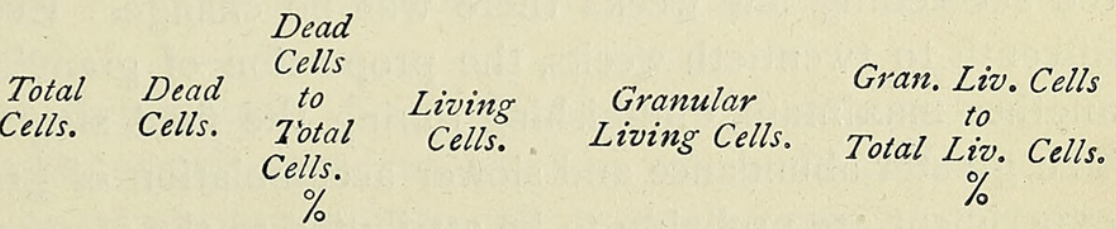

March II

March I3

Compounded value for Mar. II and Mar. I3

$3368 \quad 3^{6} 5$

149

7

$2 \mathrm{I} 34$

I4I 5

66

$5^{6} 3^{1} \quad 5^{14} \quad 9$

3003

I6I I

53

Greatest deviation from mean value

March 20

March 2 I

2

5I37

3026

59

Compounded value for Mar. 20 and Mar. 2 I

Greatest deviation trom mean value

$\begin{array}{rrrr}2609 & 203 & 8 & 24 \mathrm{I} \\ 2 \text { II } 9 & 280 & 13 & 183 \\ 4728 & 483 & 10 & 425 \\ & & 3 & \end{array}$

$1621 \quad 67$

I 397

3018 
The fact that successive points on the curves are fairly consistent suggests that, in the worst case, errors are not likely to exceed those given in the above examples. In view of the present lack of information on the subject, no attempt has been made to smooth out the curves.

To return to the desiccation experiments themselves, both afforded the same general result. During the first few weeks of desiccation, the proportion of living cells containing granules increased till it reached a maximum of nearly Ioo per cent., when it began to decrease, although this decrease was less marked in the second than in the first experiment. The proportion of dead cells increased rapidly at first, as though certain of the living cells had been surprised by the advent of drought. Then it remained roughly constant for a period which coincided approximately with the main production of granules, a fact which seems to point to this as the means by which the cells were coping with the desiccation. Finally, when the production of granules ceased, the proportion of dead increased.

There were, however, minor differences in the behaviour of the Alga in Experiments I and II. Thus, in the first experiment, an actual decrease in the proportion of granular cells occurred during the first week, so that it became reduced to $I_{5}$ per cent.; the subsequent increase to the maximum was very rapid, being completed within the three following weeks; the final decrease was considerable. The granules in individual cells never became very numerous and were mostly small. The period of low mortality was brief, and the death-rate, both before and after, high ; at the end of nearly two months not a single cell remained alive. In the second experiment there appeared no preliminary decrease of granular cells, and the increase to the maximum proportion was only reached after six to nine weeks. ${ }^{1}$ During the latter part of the period of increase the granules were large and very abundant in the individual cells; big, refractive masses were also frequent. Only a small decrease in the proportion of granular cells followed, and in the succeeding few weeks there was no change. Eventually, during the fifteenth to twentieth weeks, the proportion of granular cells increased to another maximum, diminishing during the final stage of the experiment. The greater abundance and slower accumulation of granules in the second experiment are probably to be attributed to the increased temperature and sunshine and the more gradual desiccation. The mortality during the first five weeks of desiccation was slight and occurred, on the whole, at a slow rate during the remaining period of the experiment.

The accumulation of large granules in individual cells, together with the big increase in the proportion of living cells with granules, occurring when mortality is low, places beyond doubt the production of granules

1 The actual readings give two maxima, one after six weeks and another after nine weeks. (See Fig. $5, A_{2}$ ) 
during the first part of the period of desiccation. It is a more difficult matter to elucidate the converse process, an absorption of granules, which the curves indicate (cf. Fig. 5), after the proportion of living cells with granules has reached its maximum (e.g. after nine weeks in Experiment II), for even at this time the granules in a considerable number of the cells are small and scanty. Nevertheless, estimates of the proportion of living cells with numerous granules, though necessarily of an approximate nature, showed an increase during the first five weeks of Experiment II and a subsequent decrease, corresponding roughly with the similar variation in the proportion of living cells with gramules shown by the curve (Fig. $5, A_{2}$ ).

The falling off in the proportion of living cells with granules, which occurs in the latter part of both experiments, might be attributed to the death of granular cells. The latter were in fact frequently found among the dead. But in many cases at least, the increase in the number of dead cells was not nearly sufficient to account for the decrease in the above ratio. Thus, between the sixty-second and the seventy-third day of Experiment II, the percentage of granular living cells to total living cells decreased from ninety-five to eighty-three. The percentage of dead cells to total cells increased during the same period from forty-six to fifty-five. If this had been entirely due to the death of granular cells, there would only have resulted a decrease of I per cent. of granular living cells. Therefore an increase in the number of clear cells must be supposed to have occurred. This conclusion is borne out by the appearance of 40 per cent. clear cells in filaments, previously recorded as completely granular, between the fourth and sixth weeks of Experiment I.

The occurrence of a second maximum after twenty weeks in Experiment II, as well as the continued prevalence of granules in a large proportion of the living cells after the attainment of the first maximum (at the end of six to nine weeks), seems to indicate that the production of granules may extend over a long period, if the desiccation is gradual and the temperature and sunshine adequate.

A comparison of Experiments I and II shows that filaments which become stocked with large and abundant granules (as in Experiment II) are capable of much longer resistance to drought than filaments in which the granules disappear or become small and scanty (as in Experiment I). On the other hand, the continual dying of abundantly granular cells suggests that the granules themselves do not preserve the cells, but are indicative only of certain resources which the latter possess.

As described on p. 525 , granules are very commonly present in normally growing cells, and it is therefore probable that they are primarily a by-product of metabolism. Results obtained from experiments on nutrition confirm this view. Thus granules are not formed in filaments, which, though growing under otherwise normal conditions, are deprived of 
carbon dioxide, but, on the other hand, arise abundantly in filaments cultivated in 2 to 5 per cent. glucose solutions. The results of the desiccation experiments indicate that the cells can absorb the granules. Additional evidence of this is furnished by the observation that a large decrease in the proportion of living cells with granules occurred in a sample separated from the material of Experiment I, after two and a half weeks of drought, when re-watered (cf. Table I). This was too large to be attributed to an increase of living cells by division, such as would account for the actual decrease in the proportion of dead cells.

It might be concluded that desiccation in itself does no immediate harm, but that it is the interference with the nutritive processes in the cells that causes death primarily. The presence of granules may mean the possession of adequate reserves, and hence such cells remain alive for a long period. On the other hand, prolonged drought may act directly on the protoplasm and bring about death, even in cells which are richly stocked with granules.

In summer, when all activities are at their maximum, such an excess of food is produced that enough is available both for growth and the accumulation of granules (cf. p. 525). In winter, however, there is not enough material to support more than growth, and it is only when the latter is inhibited by drought that granules make their appearance in any quantity (cf. Experiment I).

The production of granules appears to be associated with a definite substance in the cell, which is not affected by iodine but stains a deep red with Sharlach R. ${ }^{1}$ This is almost habitually present, appearing when stained as larger or smaller drops distributed in the surface of the protoplasm (Fig. 6, A, s.). Under certain conditions it accumulates in the vacuoles at the ends of the cell, so that they stain as a whole (Fig. 6, B, s.), large drops being often discernible on a homogeneous ground (Fig. 6, C).

Granules have only been observed in abundance in normally growing cells when the latter contain a considerable quantity of the substance just mentioned. Such was the case with the greenhouse material referred to on p. 525 , and especially with the filaments cultivated in glucose solutions (cf. p. 5II). The granules produced during a period of desiccation are only large and numerous if the material contains a great deal of this substance on the advent of drought, and retains it for some time subsequently. This happened in the second desiccation experiment; in fact, as the desiccation set in very slowly, the soil remaining damp during the first fortnight, this substance showed a preliminary increase, possibly due to the continuance of assimilation after growth had ceased. A large proportion of the cells in the original material of the first desiccation experiment were primarily well

1 In some cases the cells became black with osmic acid, and this reaction may be due to the same substance. Its general microchemical reactions have not been studied. 
stocked with this substance, but absorbed the greater part of it during the first week of desiccation before the production of granules became apparent. Hence, possibly, the latter were small and sparse when they eventually appeared. In both experiments, as desiccation proceeded, the substance in question gradually diminished in amount, and had become exceedingly scanty by the time the granules attained their maximum abundance. This stands in contrast to the accumulation which occurred, simultaneously with the production of granules, in well-nourished cells receiving abundant watersupply.

It may be that in reality both ample nutrition and desiccation cause a concentration of this substance, which results in the formation of granules. This view receives some confirmation from the fact that small granules can be produced in cells in the right condition, by gradually withdrawing water

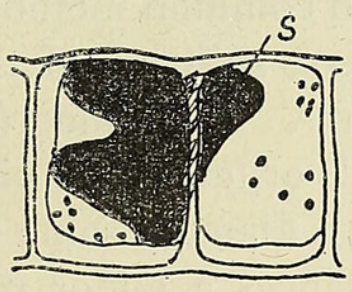

F?
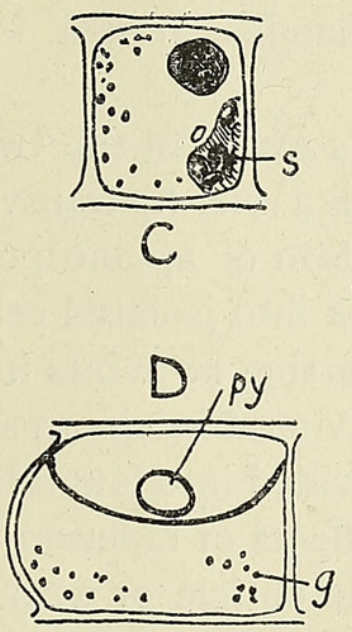

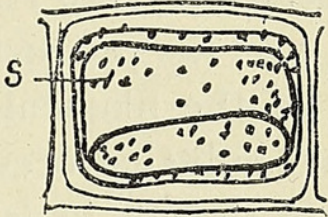

A

FIG. 6. A, cell in which the special substance stained by Sharlach R (cf. p. 532) is distributed as fine drops in the surface of the protoplasm. $B$, accumulation of the same substance in the vacuoles. C, ditto, the stained substance appearing partly in the form of large drops. D, small granules produced in a previously clear cell on the withdrawal of water from it by means of weak glycerine. S., substance stained by Sharlach R; other lettering as in Fig. I. (All figures $\times 2000$.)

from them by means of weak solutions of glycerine, sugar, or salt (Fig. 6, D). It is possible that this substance is one of the primary products of photosynthesis, while the granules constitute a secondary, reserve product.

A considerable interest centres round the relation between the production of starch and granules, since the granules also appear to be a reserve food. As a general rule, starch is scanty in cells poor in granules, and abundant in densely granular cells, so that both substances appear to accumulate under the same circumstances. For example, there was very little starch present in the material of the first desiccation experiment, but a great deal in many cells of the second desiccation experiment (see Tables I and II). Starch was abundant in the material cultivated in glucose solutions (cf. p. 53I) and in the damp greenhouse material referred to above (p. 525). Nevertheless, 
starch is frequently absent from granular cells. It is possible that there is a more direct relationship between the production of starch and the special substance referred to on p. 532. Thus they are usually either both abundant or both scanty. In the second desiccation experiment, starch remained in quantity as long as there was any appreciable amount of this substance, but tended to disappear as the latter became scanty. The relation between this substance, starch, and granules is, however, still obscure.

\section{Summary.}

A general account is given of the life of a form of Hormidium flaccidum in its native habitat. The survival of the vegetative filaments throughout successive seasons of the year is described, and the modifications to which they are subject during periods of drought, chiefly the accumulation of refractive granules, and changes in the longitudinal walls and septa, examined.

A detailed description is given of the two common methods of reproduction possessed by the Alga, viz. (i) transverse splitting of the filaments at the septa, and (ii) production of aplanospores. Regarding (i), a general breaking up of the filaments into isolated cells or few-celled pieces has not been observed, splitting occurring at points in a filament some considerable distance apart, though in favourable circumstances a minor proportion of the filaments have become divided into few-celled fragments. It is suggested that splitting is due to the effects of renewed turgor on desiccated filaments in which degeneration of the cuticle or weakening, caused by the development of mucilaginous substance between the two lamellae of the septa, has taken place. It is indicated that the production of aplanospores occurs in all seasons of the year, but is dependent on an ample supply of water. Cells giving rise to aplanospores usually contain an abundance of the special substance referred to on p. $53^{2}$ and also granules.

A white refractive substance, which appears in the cells under certain conditions in the form of granules and rounded masses, is described. This is shown to arise chiefly in the region of the polar vacuoles, but also sparsely distributed in the peripheral protoplasm. Two conditions have been observed to favour its production, viz. (i) drought, (ii) a plentiful supply of carbohydrates, e.g. glucose. It appears to be associated with a second special substance in the cell (cf. p. 532) and is possibly formed as a result of concentration of this substance. Since, in suitable circumstances, the cells are capable of eventually absorbing the granules, they evidently function as a reserve food.

It is shown that during the first weeks of a period of drought the death-rate decreases, while the abundance of granules increases to a maximum. When growing in its native habitat, the Alga in all probability 
rarely passes beyond this first stage of desiccation, as the spells of dry weather in temperate regions are comparatively short, and dew is continually deposited, especially in summer when the drought is most extreme.

I have pleasure in recording my thanks to Dr. F. E. Fritsch for his valuable help and suggestions throughout the progress of the work. My thanks are also due to Dr. E. J. Salisbury for helpful suggestions. I am glad of the opportunity to acknowledge that facilities for this research were provided by a scholarship of the Fishmongers' Company. 


\section{$2 \mathrm{BHL}$ Biodiversity Heritage Library}

Piercy, Alma. 1917. "The structure and mode of life of a form of Hormidium flaccidum, A. Braun." Annals of botany 31, 513-537. https://doi.org/10.1093/oxfordjournals.aob.a089661.

View This Item Online: https://www.biodiversitylibrary.org/item/232813

DOI: https://doi.org/10.1093/oxfordjournals.aob.a089661

Permalink: https://www.biodiversitylibrary.org/partpdf/320204

\section{Holding Institution}

Smithsonian Libraries

\section{Sponsored by}

Biodiversity Heritage Library

\section{Copyright \& Reuse}

Copyright Status: Not in copyright. The BHL knows of no copyright restrictions on this item.

This document was created from content at the Biodiversity Heritage Library, the world's largest open access digital library for biodiversity literature and archives. Visit BHL at https://www.biodiversitylibrary.org. 